\title{
HOUSING AND THE JUSTIFICATION OF \\ SCHOOL SEGREGATION
}

\section{GARY ORFIELD $\dagger$}

The intense attack on court-ordered busing rests largely on the public belief that the courts are artificially interfering with normal neighborhoods and communities. A central premise in the early Supreme Court decisions was, however, that the courts were attempting to correct violations with deep roots in both school and housing discrimination. When the Court later decided to limit and then to permit termination of desegregation, however, fundamentally different conclusions about housing were relied on-that housing segregation simply happened for some unknowable reason or that it was a natural force, separate from schools, that courts could do nothing about. The changing conception of housing, often reached with little or no empirical basis, has provided a principal grounds for judicial acceptance of segregated education.

To determine whether or not court-ordered desegregation in urban areas is needed, justifiable, and feasible, courts must reach decisions about urban residential segregation and its relationship to schools. The radical change in the Supreme Court's understanding of the relationship between school and housing segregation between the early 1970 s and the 1974 Milliken $v$. Bradley ${ }^{1}$ decision, which brought an end to significant increases in desegregation and locked in the isolation of minority students in the metropolitan North, provided a key element in the justification of a constitutional policy that made desegregation a right without a remedy in the metropolitan North, where virtually all major cities have large majorities of nonwhite students who attend segregated and inferior schools.

The Milliken decision, blocking desegregation in the North, and the 1991 and 1992 decisions, Board of Education v. Dowell ${ }^{2}$ and Freeman v. Pitts, ${ }^{3}$ permitting resegregation of southern school districts, rest to a considerable degree on court findings about housing segregation, theories that changed drastically as the courts moved from requiring all-out urban desegregation within school

\footnotetext{
+ Professor of Education and Social Policy, Graduate School of Education, Harvard University.

1418 U.S. 717 (1974).

2498 U.S. 237 (1991).

${ }^{3} 112$ S. Ct. 1430 (1992).
} 
districts to approving local decisions to send children back to segregated schools. The changing description of housing and its relationship to schools provided a central intellectual justification for a sweeping reversal of legal conceptions.

In the late 1960s and early 1970s the Supreme Court set the clear policy that where there was unconstitutional segregation there must be full and immediate desegregation. This was the primary and urgent goal. In Milliken the Court provided no remedy or, worse, a counterproductive and very limited remedy for a clear constitutional violation, futilely trying to desegregate black children in an overwhelmingly black and rapidly changing city school district. The primary constitutional value became the autonomy of the suburban school districts rather than the correction of unconstitutional segregation. This shift was made possible by a theory of suburban innocence that excluded all discussion of how the Detroit suburbs came to be among the nation's most rigidly segregated in terms of housing and, therefore, in terms of schools.

Segregated urban school systems are built on a base of housing segregation. The vast differences between inner-city and suburban schools help determine where families with choices will live, as people moving to a new metropolitan area will almost immediately discover from realtors and relocation services. In many ways, the struggle over urban desegregation has been an effort to reverse some of the educational inequalities growing out of a comprehensive system of urban segregation including schools, housing, and employment. The system was rooted in a variety of public and private forms of discrimination that operated for many decades and have not been fundamentally changed by weak and very thinly enforced fair housing laws.

The Supreme Court's change in fundamental understanding of the role of housing in desegregation cases appeared suddenly between 1973 and 1974, and was consolidated in the decisions of the early 1990s. The new conclusions about housing radically oversimplify the issues. The previous findings were actually closer to the truth.

One of the most frequent findings in city school desegregation cases is that the school districts have located schools and drawn their attendance boundaries in ways that intensify segregation and undermine integrated schools and neighborhoods. The Supreme Court recognized the interaction of school and housing decisions in 
its first urban desegregation case, the 1971 Swann v. CharlotteMecklenburg Board of Education ${ }^{4}$ decision:

The construction of new schools and the closing of old ones are two of the most important functions of local school authorities .... Over the long run, the consequences of the choices will be far reaching. People gravitate toward school facilities, just as schools are located in response to the needs of people. The location of schools may thus influence the patterns of residential development of a metropolitan area and have important impact on composition of inner-city neighborhoods. ${ }^{5}$

The first northern desegregation Supreme Court decision, Keyes v. School District No. $1,{ }^{6}$ rose directly out of issues related to neighborhood residential change. In Denver an integrated neighborhood called Park Hill feared that school boundary changes would result in the resegregation of local schools while protecting outlying white areas. Neighborhood leaders initiated the case to try to force attendance boundaries that would support integration. This dispute later became a city-wide lawsuit and produced the first Supreme Court decision on desegregating northern cities.

The 1973 decision found that the Denver district's practices labeled schools according to race and, pointing to school siteselection and attendance boundaries that tended to resegregate an integrated community, affected the racial makeup of neighborhoods throughout the city's housing market. The complex interaction between school and housing segregation with broader housing effects was a key part of the Supreme Court's reasoning for ordering city-wide desegregation on the basis of neighborhood level violations:

First, it is obvious that a practice of concentrating Negroes in certain schools by structuring attendance zones or designating "feeder" schools on the basis of race has the reciprocal effect of keeping other nearby schools predominantly white. Similarly, the practice of building a school ... to a certain size and in a certain location, "with conscious knowledge that it would be a segregated school," ... has a substantial reciprocal effect on the racial composition of other nearby schools. So also, the use of mobile classrooms, the drafting of student transfer policies, the transportation of students, and the assignment of faculty and staff, on

\footnotetext{
402 U.S. 1 (1970).

${ }^{5}$ Id. at 20.

${ }^{6} 413$ U.S. 189 (1973).
} 
racially identifiable bases, have the clear effect of earmarking schools according to their racial composition, and this, in turn, together with the elements of student assignment and school construction, may have a profound reciprocal effect on the racial composition of residential neighborhoods within a metropolitan area, thereby causing further racial concentration within the schools. We recognized this in Swann . . . .

\section{Protecting the Suburbs}

What the Supreme Court recognized in Swann and Keyes it forgot in Milliken, which came just a year after the Denver case. Confronted with the decision whether to order desegregation across metropolitan areas or to block it at the suburban boundary lines, the Court faced an issue full of housing dimensions but totally excluded housing from its decision, which made desegregation in Detroit and many other large cities impossible. This decision brought to an end the rapid growth of desegregated schooling for black students since the mid-1960s and blocked any significant desegregation for the soaring Latino population. The decision set the stage for the resegregation cases of the 1990s.

The most important school decision for the North rested on a majority opinion ignoring housing evidence in the record of a case brought in one of the nation's most intensely segregated metropolitan areas. Metropolitan Detroit had seen a great deal of governmental action to foster segregated communities. Chief Justice Burger's opinion for the five-member majority claimed that the issue was not raised, although the issues were extensively addressed in the trial and in the oral argument citing the evidence and trial court findings on housing.

Since the early 1970s the courts and policymakers have increasingly turned away from serious discussion of the system of urban segregation. By the time of the resegregation decisions of the 1990 s, housing came to be seen as a reason justifying reinstatement of school segregation rather than part of a problem that required a comprehensive solution.

As federal courts changed direction while continuing to affirm the Brown v. Board of Education ${ }^{8}$ decision, they explained that the increasing segregation in many districts was not a public responsi-

${ }^{7} I d$. at 201-02 (footnotes and citations omitted).

${ }^{8} 347$ U.S. 483 (1954). 
bility, but a natural process reflecting private preferences. If spreading segregation is natural and private, it is beyond the reach of the courts and futile for them to try to change-and is therefore an important justification for judicial inaction while schools are resegregated.

\section{SHIFTING THE BURDEN}

Basic assumptions about urban change by the Supreme Court majority in key decisions sustaining segregation, including Milliken and the resegregation decisions of the 1990s, are in conflict with much research on housing. The conclusions of some lower courts in approving resegregation include findings that incorrectly attribute all white enrollment decline to a busing plan when there has been very similar enrollment change in similar cities without busing plans and even in cities that restored neighborhood schools.

It is easy in most cities to show that housing segregation was initiated and institutionalized with massive official support, that most minority neighborhoods that were segregated remain segregated today, and that there are still great numbers living in racially defined housing markets, although surveys show that very few minority adults prefer to live in all-minority neighborhoods. Segregation has been spreading on the borders of existing minority communities since World War I.

If it is enough to show substantial evidence of historical and current discrimination and an unbroken pattern of ghetto expansion dating back to decades of overt discrimination, then housing issues must always be considered in school desegregation cases. It is easy to demonstrate various forms of housing discrimination historically in most housing markets and to show that segregation has been continuous. Some of the principal barriers to housing integration, such as racial fears, the creation of racially defined submarkets and real estate operations, and the unequal knowledge about various communities, are clearly rooted in the history of discrimination.

No one, however, can prove all the linkages between the past and present. There are such imperfect measures of many of the key forces, and so many other things changed in metropolitan areas as the form of housing segregation evolved that there is no way to scientifically prove how much of contemporary segregation is or is not directly linked to historic violations. If the court requires specific proof of the various linkages and specific evidence of the 
precise current impacts, it is setting an impossible standard of proof, and the civil rights side will surely lose although there are doubtless major linkages.

The courts in the resegregation cases often impose demanding standards of proof for plaintiffs but make their own findings of fact about housing by simple assertion. In some cases the courts reach sweeping and extremely controversial conclusions about housing by simply announcing them as if they were common sense. In others they make findings about the causes of segregation on the basis of surveys of racial attitudes, which cannot, in their nature, assess the two fundamental legal issues: (i) the degree to which the attitudes are a product of the history of discrimination and segregation; and (ii) the degree to which they would change under a new policy. Although surveys are often presented by school districts as if they show natural preferences that constrain rather than result from public policy, surveys cannot provide such answers. The attitudes reported could well be partly shaped by previous housing segregation policies. Courts often take surveys and treat the attitudes as if they are simply natural and permanent attitudes-a totally inappropriate use of survey data. If such standards had been used at the time of the Brown decision, the fact that eighty-one percent of white southerners believed the Court to be wrong would have been taken as a justification for inaction, and we would have never known that forty years later only fifteen percent of white southerners would hold that attitude after experiencing the reality of the nation's most integrated schools.

Sometimes the intellectual enterprise of the courts is even more unfounded. A court may, for example, simply announce that all historic housing violations that happened before the date the Fair Housing $\mathrm{Act}^{9}$ was enacted in 1968 have no lasting effects because the law canceled the effects of generations of overt discrimination. These findings ignore the federal government's own research on the persistence of discrimination in housing markets and the records and studies showing the very slight enforcement of the Fair Housing Act. Because the levels of segregation in many areas are little changed, tests show continued discrimination, and because many of the same subsidized projects are as segregated or more than before, it is difficult to understand the basis for the findings.

${ }^{9}$ Fair Housing Act of 1968, Pub. L. No. 90-284, 801-19, 82 Stat. 73, 81-89 (codifed as amended at 42 U.S.C. $\$ \S 3601-3619$ (1988)). 
A more moderate version of this approach might be called the steadily vanishing violation theory. It simply asserts that historic violations have diminishing effect with the passage of time. Instead of assuming that the enactment of fair housing laws ended discrimination, it assumes that discrimination steadily declines and, over a number of years, could be safely discounted. This theory also is simply asserted. There is no empirical basis for asserting that the passage of time solves discrimination and prejudice. In fact, racial attitudes change in both directions.

Some courts raise even more extensive barriers to considering the housing issues. In Swann the Supreme Court had noted that not too much should be put into one case because a single case "can carry only a limited amount of baggage. ${ }^{10}$ This obscure phrase gave lower courts a plausible way to dispose of even extremely serious housing issues, while posing impossible barriers for civil rights plaintiffs. If such plaintiffs bring in limited evidence, it will not show the needed proof of continuing effects of past violations; but if they try to prove the whole intricate history of metropolitan discrimination in a housing market it may be dismissed as too much "baggage." The Supreme Court, for example, affirmed lower court decisions rejecting extremely extensive evidence on the intentional residential segregation of metropolitan Atlanta partially on the "baggage" theory. If the courts require evidence of a history of discrimination in housing to integrate metropolitan schools in residentially segregated communities and then dismisses extremely powerful evidence as too complicated for the courts to think about, plaintiffs confront a maze with no exit.

In its key decisions on resegregation, Dowell and Pitts, the Supreme Court revisited the housing issue, but was deeply divided on whether there was a relationship that could justify either courts relinquishing jurisdiction over school systems or courts holding school systems accountable for spreading residential segregation. The Pitts case shows fundamental division on the housing issues in "concurring opinions" expressing totally different understandings of the basic relationship between schools and housing. The justifications that the Court's majority appeared to rely on in the resegregation cases included a mixture of switching the burden of proof, assuming that time cured the effects of past discrimination, and accepting the natural preferences theory of segregation on the

${ }^{10} 402$ U.S. at 22. 
basis of surveys commissioned by lawyers attempting to end desegregation orders.

The issue of housing deserves much more sophisticated consideration because theories of housing change are very directly related to decisions about ending school desegregation. If housing segregation is caused or strongly affected by school desegregation plans, then any plan for lasting integration must take housing into account. If the courts, on the other hand, see housing segregation as unrelated to school desegregation and essentially private, they are likely to conclude that school officials may accept a "natural" spread of residential segregation occurring through private choice and not public action, and therefore to accept the spread of school segregation as natural. This is precisely the picture of housing painted by school districts seeking permission to resegregate and accepted by lower court judges.

At the other extreme would be clear proof of a variety of forms of public action that greatly intensify housing and school segregation. Housing actions could include, for example, segregated location and tenant assignment for subsidized housing projects; administration of housing voucher and certificate programs in ways that undermine and resegregate integrated neighborhoods; the use of zoning power to block minority housing; and discrimination in federally supervised mortgage lending institutions. Lack of significant enforcement of fair housing laws in the face of blatant housing discrimination would add to the case. All of these problems could be compounded by school district decisions to build new schools certain to be segregated, to downgrade the curriculum in racially changing schools, and other actions contributing to school and housing resegregation. This is the situation described by civil rights lawyers and supported by a considerable body of research. Repairing school segregation in this case would require dealing with the effects of housing segregation or attacking housing discrimination itself.

The school segregation that exists in any given community is likely to reflect some complex combination of current discrimination in schools and housing, the enduring effects on practices, inequalities, and expectations rooted in past discrimination, and the effects of private prejudice and private preferences, which may themselves be products of earlier discrimination.

The segregated schools that dominate metropolitan America in the 1990 s are primarily a reflection of persistent housing segregation. The serious segregation today is overwhelmingly among 
school districts rather than within school districts. Concentration of three-fourths of the nation's residents and more than eighty percent of minority students in metropolitan areas, fragmentation of most of those areas into many school districts, and concentration of the African-American and Latino students in a small number of those districts produce and maintain segregation. Segregated minority housing continues to spread, reaching out into important sectors of some suburban rings, and the growth on the suburban periphery continues to be in communities that are virtually all white.

The powerful role of housing and school district fragmentation in contemporary school segregation raises very difficult questions for courts attempting to realize the goals of Brown and Green $v$. County School Board. ${ }^{11}$ Recognizing the linkages between schools and housing, and working on their positive potentials will move us toward the goal of successfully integrated communities with naturally integrated and equitable schools-and will begin to mobilize many kinds of policy toward that goal. We need policies, for example, to recognize and support stably integrated neighborhoods and to reward them with excellent "naturally integrated" neighborhood schools. School districts need to have a role in housing development decisions and housing developers need to help integrate new neighborhoods. Subsidized housing vouchers, as suggested by the Clinton Administration, need to be combined with strong counseling to permit more of these families to obtain housing in areas with excellent integrated schools.

There is ample experience now to devise mutually supportive school and housing integration policies to overcome the remains of generations of intentional segregation. Ironically, it may be that the most complex and wide-ranging planning of school and housing remedies will lead to the most natural, stable, and least coercive outcome. If the courts choose, on the other hand, to use unsupported presumptions and burden shifts about housing issues to justify resegregation of schools, decades of commitment to the goals of Brown will give way to quiet acceptance of segregated schools serving segregated neighborhoods. Our courts have been attempting to use ill-founded theories about housing to justify turning back to Plessy v. Ferguson ${ }^{12}$ in metropolitan America. There is massive evidence that this will lead only to the development of the kind of 
"inherently unequal" schools the Court warned against in Brown. A much better path is to accept the powerful public responsibility for building and spreading the system of urban apartheid and to begin to put in place remedies that could lead toward a more integrated urban society. 